\title{
ŠEIMINIS PIKTYBINĖS HIPERTERMIJOS ATVEJIS
}

\author{
Diana Damanskytė, Kristina Česevičiūtė, Ilona Razlevičè, Lina Kalibatienė, \\ Tomas Bukauskas, Andrius Macas \\ Lietuvos sveikatos moksly universiteto Medicinos akademijos Anesteziologijos klinika
}

Raktažodžiai: piktybinè hipertermija, anestezijos komplikacijos, hipermetabolinis sindromas.

\begin{abstract}
Santrauka
Piktybinè hipertermija (PH) - paveldimas skeleto raumenų funkcijos sutrikimas, kuriam būdingas hipermetabolinio sindromo vystymasis veikiant gariniams anestetikams ir/ar depoliarizuojantiems raumenu relaksantams. Pateikiame piktybinès hipertermijos atveji, kuris ívyko 3 metų pacientui bei keliems jo giminaičiams. Kadangi paciento išgyvenamumas priklauso nuo ankstyvo piktybinès hipertermijos krizès atpažinimo ir neatidèliotinos gydymo pradžios, norime aptarti būkles, kurių metu galimas piktybinės hipertermijos išsivystymas, jos klinikinius simptomus ir gydymo galimybes.
\end{abstract}

\section{Ivadas}

Piktybinè hipertermija yra farmakogenetinis sindromas, paveldimas autosominiu dominantiniu būdu. Tai retai pasitaikanti, tačiau gali būti mirtina komplikacija anestezijos metu. $\mathrm{PH}$ pasireiškia pacientams, turintiems skeleto raumenų receptorių defektų, dèl kurių kalcis kaupiasi sarkolemoje, veikiant tam tikrai anestetinei medžiagai [1]. Piktybinès hipertermijos krizès metu pasireiškia ląstelių hipermetabolizmas, dèl to vystosi ilgalaikis raumenų susitraukimas ir raumens pažeidimas (rabdiomiolizè), anaerobinis metabolizmas, acidozè [2]. Visų šių procesų pasekmė yra širdies sustojimas. LSMUL KK per pastaruosius 30 metu registruoti vos keli PH atvejai, kurie baigèsi sèkmingai. Pateikiame klinikini atvejį, kuris ìvyko pacientui ir, kaip vèliau išaiškejjo, paciento senelio broliui.

Darbo tikslas: aptarti šeiminį piktybinès hipertermijos atveji.

\section{Klinikinis atvejis}

2 m. 11 mèn. amžiaus pacientas stacionarizuotas ị LSMU Kauno klinikų Ausų, nosies, gerklès ligų skyrių planinei adenoidų šalinimo operacijai. Apie 1 metus laiko berniuką vargino pasunkèjęs kvėpavimas pro nosị, dažnos slogos, o taikytas konservatyvus gydymas buvo neefektyvus. Pacientas svèrẻ $15 \mathrm{~kg}$, jokių kitų šalutinių ligų ir operacijų neturejjo, alergijų tèvai nepastebejo. Laboratoriniai kraujo tyrimai buvo normos ribose. Prieš operaciją gydytojo anesteziologo ivvertintas I ASA klase, numatyta bendroji endotrachejinè anestezija. Sutikimas anestezijai pasirašytas berniuko tèvų. Taikyta anestezijos indukcija sevoflurano kauke, aseptikos sąlygomis paruošus punkcijos vietą punktuota ir kateterizuota periferinè vena, skirta kristaloidų infuzija. Pradètas ịprastas gyvybinių funkcijų monitoravimas (EKG, neinvazinis AKS, $\mathrm{SpO}_{2}$, etCO ${ }_{2}$ ). Skirta $20 \mu \mathrm{g}$ fentanilio, $3 \mathrm{mg}$ mivakuriumo $\mathrm{i} / \mathrm{v}$. Pacientas intubuotas tiesioginès laringoskopijos metu, illeistas $4 \mathrm{~mm}$ skersmens intubacinis vamzdelis su manžete. Anestezijai palaikyti operacijos metu skirtas sevofluranas. Netrukus po intubacijos pradejjus dirbtinę plaučių ventiliaciją, stebètas didelis $\mathrm{CO}_{2}$ kiekis iškvèpime $(72 \mathrm{mmHg})$. Atsiurbta iš intubacinio vamzdelio, skirti du ịpurškimai inhaliuojamojo salbutamolio, didinta deguonies frakcija iki 100\%, keisti dirbtinès plaučių ventiliacijos režimai. Nepaisant taikytų veiksmu, slègis kvėpavimo takuose išliko padidèjęs (26-28 $\left.\mathrm{cmH}_{2} \mathrm{O}\right), \mathrm{CO}_{2}$ kiekis iškvépime nemažejo. Pacientas buvo perintubuotas, tačiau ir po pakartotinès intubacijos didejo $\mathrm{CO}_{2}$ kiekis iškvėpime $(72 \rightarrow 82 \rightarrow 92 \mathrm{mmHg})$, išryškejjo visų skeleto raumenų rigidiškumas. Pradèta stebèti kūno temperatūra, kuri sieke $38,5^{\circ} \mathrm{C}$. İtarus piktybinę hipertermiją nutrauktas sevoflurano skyrimas, pakeistas kvėpavimo kontūras ir adsorbentas, pacientas ventiliuotas $100 \%$ deguonimi, skiriant didelio tūrio minutinę ventiliaciją. Temperatūros mažinimui skirta $300 \mathrm{mg}$ paracetamolio $\mathrm{i} / \mathrm{v}$. Pradètas lašinti dantrolenas $2,5 \mathrm{mg} / \mathrm{kg}$ (iš viso $37,5 \mathrm{mg}$ ), paimtas kraujo méginys laboratoriniams tyrimams: $\mathrm{K}^{+}$, kreatinino, kreatininfosfokinazès (KFK), gliukozės, šlapalo koncentracijoms nustatyti, krešejimo rodikliams įvertinti. Po taikyto gydymo būkle pradejjo gerèti, rigidiškumas išnyko, pacientas pats pradejjo kvèpuoti. $\mathrm{CO}_{2}$ kiekis iškvėpime sumažejo iki 40 $\mathrm{mmHg}$, temperatūra nukrito iki $37,4^{\circ} \mathrm{C}$. Planinè operacija neatlikta. Tolimesniam gydymui pacientas pervežtas ị vaikų intensyviosios terapijos skyrių, kur buvo tęsiamas dantroleno 
skyrimas (15 mg kas 6 val). Eigoje stebèta didejjanti KFK koncentracija (7248 $\rightarrow 9605$ IU/l), pradètas šlapimo šarminimas, skiriant natrio bikarbonatą per skrandinị zondą $(8 \mathrm{ml} / 4$ k./d.). Po paros pacientas ekstubuotas. KFK mažejo ( 8178 $\rightarrow 3387 \rightarrow 473$ IU/1). Trečią gydymo dieną pacientas buvo perkeltas į vaikų vidaus ligų skyrių, o praejjus septynioms dienoms išleistas ị namus.

Po įvykio tikslinant anamnezę sužinota, kad paciento senelio broliui operacijos metu taip pat buvo registruota piktybinè hipertermija. Iš archyve esančios ligos istorijos sužinota, kad 2006 m. veido-žandikaulių chirurgijos operacineje nuskausmintas $61 \mathrm{~m}$. berniuko senelio brolis dèl seilių liaukos uždegimo. Skundèsi kelias paras didejjančiu dariniu pažandès srityje bei sutrikusiu kramtymu. Sirgęs išemine širdies liga, arterine hipertenzija, žvyneline, prieš kelis metus persirgęs miokardo infarktu. Operacijų neturèjo, alergijų nepastebėjo. Numatyta pažandžio seilių liaukos šalinimo operacija bei bendroji endotrachèjinè anestezija. Anestezijos indukcijai skirtas fentanilis, tiopentalis ir atrakuriumas. Anestezija tęsta sevoflurano garais. Praejjus 30 min. nuo anestezijos pradžios stebėtas didejjantis ŠSD iki $120 \mathrm{k} . / \mathrm{min}$., hipertenzija iki 180/97 mmHg, ị taikomą gydymą opioidais bei antihipertenziniais medikamentais atsako nebuvo, minèti rodikliai toliau augo. Kapnogramoje 45 min. po intubacijos stebètas $\mathrm{CO}_{2}$ kiekio iškvèpime augimas $(68 \rightarrow 76 \rightarrow 118 \mathrm{mmHg})$, temperatūros nosiarykleje didejimas $\left(36,8 \rightarrow 39,6 \rightarrow 40,9^{\circ} \mathrm{C}\right)$, raumenų rigidiškumas. Itarta piktybinè hipertermija. Skirti šalti tirpalai $\underset{i}{i} / \mathrm{v}$, nutraukti inhaliaciniai anestetikai, pakeistas kvėpavimo kontūras ir adsorbentas, pradètas patogenetinis gydymas dantrolenu 2 $\mathrm{mg} / \mathrm{kg}$ (viso $200 \mathrm{mg}$ ), paimti kraujo tyrimai (bendras kraujo tyrimas, kalis, natris, urea, kreatininas, krešumo rodikliai), kateterizuota šlapimo pūslè. Atliktame kraujo dujų tyrime $\mathrm{PaCO}_{2}$ išmatuotas $138 \mathrm{mmHg}$. Skiriant gydymą, po valandos $\mathrm{CO}_{2}$ kiekis sumažèjo iki $68 \mathrm{mmHg}$, kūno temperatūra iki $39,1^{\circ} \mathrm{C}$. Pacientas neekstubuotas, ventiliuojamas portatyviniu dirbtinès plaučių ventiliacijos aparatu, tolimesniam gydymui palydetas ị intensyviosios terapijos skyrių, kur buvo tęsiamas šaldymas išorinèmis fizinėmis priemonèmis, šaltais skysčiais bei konservatyvus gydymas nebeskiriant dantroleno. Tą pačią dieną pacientas ekstubuotas, po paros perkeltas i veido-žandikaulių chirurgijos skyrių. Vèliau sužinota, kad ne tik berniuko senelio broliui ịvyko PH krizè, tačiau prieš daug metu (apie 1970 metus) operacijos metu staiga mire ir minèto giminaičio mama, kurios mirtis galejjo įvykti taip pat dèl PH.

\section{Diskusija}

Piktybinė hipertermija $(\mathrm{PH})$ - paveldimas skeleto raumenų funkcijos sutrikimas, kuriam būdingas hipermetabo- linio sindromo vystymasis veikiant gariniams anestetikams (pvz., halotanui, izofluranui, sevofluranui, desfluranui) ir/ ar depoliarizuojantiems raumenų relaksantams (pvz., sukcinilcholinui). Paveldima autosominiu dominantiniu būdu $[3,4]$. Pirmos eilès giminaičiams (broliams, seserims bei vaikams) yra 50\% tikimybè paveldèti minètą sutrikimą [1]. Genetinis polinkis yra susijęs su RYR1 geno mutacijomis, kurios aptinkamos 19q13.1 chromosomoje [3]. Taip pat nustatyta ir CACNA1S geno mutacija, kuris nulemia $1 \%$ PH atvejų [3,5], manoma, kad STAC3 mutacija gali būti susijusi su PH [6]. RYR1 genas koduoja pakitusius rianodino receptorių baltymus, atsakingus už $\mathrm{Ca}^{2+}$ išsiskyrimą iš sarkoplazminio tinklo ị sarkoplazmą, dèl to vyksta kalcio kaupimasis ir veikiant anestetinei medžiagai yra sukeliamas ilgalaikis skeleto raumenų susitraukimas $[2,3,7,8]$.

Tikrasis ligos dažnis nėra žinomas, nes nèra paskelbto visuotinio registro, tačiau literatūros duomenimis, $\mathrm{PH}$ paplitimas svyruoja 1:10 000 iki 1:100 000 anestezijų [2,9]. Paplitimas tarp vaikų yra 1:15000, o suaugusiujų - 1: 15000 - $1: 50000[7,10]$. Vaikai sudaro $45-52 \%$ visų minimų PH įvykių. Šis sindromas 2,5-4,5 karto dažniau pasireiškia vyrams, tačiau mirtingumas žymiai didesnis tarp moteru $[2,4,7,11]$.

PH krizès metu dèl pagreitejusio aerobinio metabolizmo didèja anglies dioksido produkcija ir ląstelių acidozè bei yra išeikvojami energetiniai substratai (deguonis ir adenozino trifosfatas) [2]. Prasideda anaerobinis metabolizmas, kuris gilina acidozę bei skatinama laktatų produkcija [2]. Išeikvojus energetines medžiagas vystosi rabdiomiolizè, kurios metu pasireiškia hiperkalemija ir mioglobinurija [2]. Pateikto klinikinio atvejo metu berniukui stebeti simptomai, kurie neabejotinai leido įtarti PH: hiperkarbija, kuri progresavo nepaisant taikomų gydymo priemonių, bei visų skeleto raumenų rigidiškumas. Vèlyvieji PH požymiai - tokie kaip didejanti šerdinè kūno temperatūra bei KFK kiekis kraujo serume taip pat buvo nustatyti minètam pacientui.

Literatūroje minima, kad vaikams PH krizès metu dažniausiai pasireiškia sinusinè tachikardija, hiperkarbija ir greitas temperatūros didejjimas [2,12]. Skirtingo amžiaus vaikų grupèse klinikiniai simptomai gali skirtis: vaikams iki 24 mèn. amžiaus dažnesnis odos bẻrimas, didesnè laktatų bei mažesnè KFK koncentracija [2]. Vaikams nuo 2 iki 12 metų amžiaus dažniau pasireiškia kramtomojo raumens spazmas, mažesnis maksimalus etCO $\mathrm{C}_{2} \mathrm{PaCO}_{2}$ kiekis $[2,12]$. $12-18$ metų vaikams stebima aukštesnè maksimali temperatūra bei greitesnis temperatūros kilimas, gausesnis prakaitavimas, didesnis kalio bei KFK kiekis, ilgesnè trukmè, kol pasiekiamas maksimalus etCO $\mathrm{C}_{2}$ lygis $[2,12]$. Toks skirtumas aiškinamas tuo, kad vyresniems vaikams būdinga didesnè raumenų masè, todèl rabdomiolizès raiška gali būti stipresnè [14]. Mūsų 
berniukas patenka ị viduriniają vaikų grupę, klinika atitiko minètus simptomus, stebètas ryškus skeleto raumenų rigidiškumas nepaisant taikytos bendrosios anestezijos su raumenu relaksantais. Tuo tarpu suaugusiems pirmiausia stebimas didejantis $\mathrm{CO}_{2}$ kiekis iškvėpime, raumenų rigidiškumas, tachikardija ir temperatūros didejimas. Berniuko senelio broliui iš pradžių stebetas didejantis ŠSD ir AKS ir tik po to išryškejjo hiperkarbija bei skeleto raumenų rigidiškumas.

PH turi būti visada ịtariama, kai anestezijos metu skiriami PH provokuojantys medikamentai, nes daugiau nei 90\% PH krizès atvejų pasireiškia pacientams, kurie turi neigiamą šeiminę anamnezę ir net daugiau nei pusẻ atvejų ìvyksta pacientams, kuriems anamnezejje anestezijos praejo sklandžiai $[2,13,14]$. PH diagnozè neabejotina, kai yra ịvykusi PH ankstesnès anestezijos metu ir kai nustatyti būdingi raumenų funkcijos sutrikimai tiriant raumenų biopsinę medžiagą (kofeino-halotano kontrakcijos testo metu, kuris, 2017 m. duomenimis, atliekamas tik 30-yje pasaulio centrų) bei nustačius PH būdingas jau minètas genų mutacijas [5]. Kofeino-halotano kontrakcijos testas yra vienintelis laboratorinis testas piktybinès hipertermijos sindromui diagnozuoti, tačiau gali būti sunku interpretuoti rezultatus pacientams, sergantiems raumenų liga, nes pati liga gali paveikti atsaką i halotaną ir/ar kofeiną [15]. Diagnozė yra tikètina, jei paciento giminaičiui diagnozuota $\mathrm{PH}$ ar pacientas serga paveldima raumenų liga, sukelta RYR1 geno mutacijos (šerdine miopatija, King-Denborough sindromu, Multi/Minicore liga, Nemaline miopatija, Evanso miopatija) [16]. Sergantiems kitomis miopatijomis anestezijos metu gali būti sukeliamos ị PH panašios reakcijos, todèl reikia vengti $\mathrm{PH}$ provokuojančiuc veiksnių [16,17]. Itarti esančią raumenų problemą galima ir iš atitinkamų klinikinių simptomų (hipotonija naujagimystès laikotarpiu, sąnarių kontraktūros, pavėluotas motorinis vystymasis, skausmingi spazmai, raumenų nykimas ir silpnumas, neišraiškingi veido bruožai, ,anties“ eisena, tachikardija ramybejje) bei atliktuose tyrimuose stebint besimptomį KFK padidejimą, atrioventrikulinio laidumo sutrikimus elektrokardiogramoje [18]. Atskirti miopatiją dažniausiai padeda tik atlikti detalūs histopatologiniai, radiologiniai (BMR) ir genetiniai tyrimai [19].

Paciento išgyvenamumas priklauso nuo ankstyvo $\mathrm{PH}$ krizès atpažinimo ir neatidèliotinio gydymo pradžios [14]. Ivvkus PH krizei pimiausia svarbu nutraukti garinio anestetiko tiekimą, taikyti 2-3 kartus didesnę minutinę ventiliaciją, skirti $100 \%$ deguoni, pakeisti $\mathrm{CO}_{2}$ absorbento konteineri nauju, informuoti chirurgą apie ịvykusią nepageidaujamą klinikinę situaciją. Negalint nutraukti ir atidèti operacijos, tęsti nuskausminimą taikant visišką intraveninę nejautrą (TIVA) bei kuo greičiau pradèti patogenetini gydymą dantrolenu $[2,14]$. Dantrolenas - tai rianodino receptorių antagonistas, sustabdantis kalcio jonų judejjimą iš sarkoplazminio tinklo. Mūsų klinikinio atvejo metu laiku įvertintas galimas PH pasireiškimas ir pradètas tinkamas gydymas, todèl paciento baigtis buvo gera. Dantrolenas turi būti privalomas ir lengvai prieinamas visose ligoninėse, kuriose atliekamos anestezijos, naudojant $\mathrm{PH}$ provokuojančius vaistus $[20,14]$.

$\mathrm{PH}$ grèsmę galima būtų ịtarti, jeigu berniuko tèvai prieš numatytą operaciją būtų daugiau žinoję apie buvusius PH atvejus gimineje, tačiau šeimine anamneze labiau pasidomèta tik tada, kai anesteziologas artimuosius informavo apie nutikusi ịvykị. Literatūroje teigiama, kad yra 50\% tikimybė paveldèti PH sindromą pirmos eilès giminaičiams [1], tačiau pateiktos situacijos atveju, nors abu pacientai yra tolimi giminaičiai, bet abiem stebèta ta pati komplikacija.

\section{Išvados}

Piktybinè hipertermija yra reta, bet gyvybei labai pavojinga būklè, progresuojanti anestezijos metu, veikiant tam tikrai anestetinei medžiagai. Todèl labai svarbu laiku itarti PH ar i PH panašias reakcijas, jas diferencijuoti ir kuo greičiau pradèti atitinkamą patogenetini gydymą. Privalu kiekvienoje gydymo ịstaigoje turèti PH gydymo protokolus, būti pasiruošusiam šiai klinikinei situacijai bei taikyti TIVA ar apsvarstyti regioninès anestezijos metodų naudojimo galimybes, tiek jau esant žinomai PH, tiek sergant paveldimomis raumenų ligomis. Atlikti genetiniai tyrimai bei kofeinohalotano kontrakcijos testas padeda nustatyti šią patologiją ir išvengti galimų letalių baigčių, susijusių su anestezija.

\section{Literatūra}

1. Litman RS. Susceptibility to malignant hyperthermia: Evaluation and management. UpToDate [serial online] $2017 \mathrm{Jul}$ [cited 2018 Apr 18]. Available from: URL: https://www.uptodate.com/contents/susceptibility-to-malignant-hyperthermiaevaluation-and-management.

2. Litman RS. Malignant hyperthermia: Clinical diagnosis and management of acute crisis. UpToDate [serial online] 2017 Sep [cited 2018 Apr 18]. Available from: URL: https://www. uptodate.com/contents/malignant-hyperthermia-clinical-diagnosis-and-management-of-acute-crisis.

3. Salazar JH, Yang J, Shen L, Abdullah F, Kim TW. Pediatric malignant hyperthermia: risk factors, morbidity, and mortality identified from the Nationwide Inpatient Sample and Kids Inpatient Database. Pediatric Anesthesia 2014;24:1212-1216. https://doi.org/10.1111/pan.12466

4. Schneiderbanger D, Johannsen S, Roewer N, Schuster F. Management of malignant hyperthermia: diagnosis and treatment. Therapeutics and Clinical Risk Management 2014;10:355-362.

5. Chapin JW. Malignant hyperthermia. Medscape [serial online] 2017 Dec [cited 2018 Apr 18]. Available from: URL: https:// emedicine.medscape.com/article/2231150-overview. 
6. MacKay EJ, Wilkerson C, Kraeva N, Rosenberg H, Kennedy T. A rare genetic variant of the ryanodine receptor in a suspected malignant hyperthermia susceptible patient. Journal of Clinical Anesthesia 2016;33:144-146. https://doi.org/10.1016/j.jclinane.2016.02.038

7. Lerman J. Perioperative management of the paediatric patient with coexisting neuromuscular disease. British Journal of Anaesthesia 2011;107(S1):i79-i89.

https://doi.org/10.1093/bja/aer335

8. Japanese Society of Anesthesiologists. JSA guideline for the management of malignant hyperthermia crisis 2016. Journal of Anesth 2017;31(2):307-317. https://doi.org/10.1007/s00540-016-2305-z

9. Schwartz A, Kaplan D, Rosenzweig V, Klein M, Gruenbaum BF, Gruenbaum SE, Boyko M, Zlotnik A, Brotfain E. The incidence of hyperthermia during cochlear implant surgery in children. The Journal of Laryngology \& Otology 2017;131(10):900-906.

https://doi.org/10.1017/S0022215117001682

10. Namani PN, Moss DR. Babies in distress: malignant hyperthermia in infancy explored. Clinical Pediatrics 2015;54(6):557. https://doi.org/10.1177/0009922814556981

11. Rosero EB, Adesanya AO, Timaran CH, Joshi GP. Trends and outcome of malignant hyperthermia on the United States, 2000 to 2005. Anesthesiology 2009;110:89-94.

https://doi.org/10.1097/ALN.0b013e318190bb08

12. Nelson P, Litman RS. Malignant hyperthermia in children: an analysis of the North American malignant hyperthermia registry. Anesthesia \& Analgesia 2014;118(2):369-374. https://doi.org/10.1213/ANE.0b013e3182a8fad0

13. Larach MG, Gronert GA, Allen GC, Brandom BW, Lehman EB. Clinical presentation, treatment, and complications of malignant hyperthermia in North America from 1987 to 2006. Anesthesia \& Analgesia 2010;110(2):498-507. https://doi.org/10.1213/ANE.0b013e3181c6b9b2

14. Glahn1 KPE, Ellis FR, Halsall PJ, Muller CR, Snoeck MMJ, Urwyler A, Wappler F. Recognizing and managing a malignant hyperthermia crisis: guidelines from the European Malignant Hyperthermia Group. British Journal of Anaesthesia 2010;105(4):417-20.

https://doi.org/10.1093/bja/aeq243

15. Jurkat-Rott K, McCarthy T, Lehmann-Horn F. Genetics and pathogenesis of malignant hyperthermia. Muscle Nerve 2000;23:4-17.

https://doi.org/10.1002/(SICI)1097-4598(200001)23:1<4::

AID-MUS3>3.0.CO;2-D
16. Schieren M, Defosse J, Böhmer A, Wappler F, Gerbershagen MU. Anaesthetic management of patients with myopathies. European Journal of Anaesthesiology 2017;34:1-9. https://doi.org/10.1097/EJA.0000000000000672

17. Gray RM. Anesthesia-induced rhabdomyolysis or malignant hyperthermia: is defining the crisis important? Pediatric Anesthesia 2017;27:490-493.

https://doi.org/10.1111/pan.13130

18. Brandom BW, Veyckemans F. Neuromuscular diseases in children: a practical approach. Pediatric Anesthesia 2013;23:765769. https://doi.org/10.1111/pan.12246

19. Voermans NC, Snoeck M, Jungbluth H. RYR1-related rhabdomyolysis: A common but probably underdiagnosed manifestation of skeletal muscle ryanodine receptor dysfunction. Revue neurologique 2017;172:546-558.

https://doi.org/10.1016/j.neurol.2016.07.018

20. Sinha A K, Kumari P, Vaghela MM, Sinha C, Kumar B. Postoperative malignant hyperthermia - a medical emergency: a case report and review of literature. Journal of Clinical and Diagnostic Research 2017;11(4):1-2.

https://doi.org/10.7860/JCDR/2017/20531.9493

\section{FAMILY HISTORY OF MALIGNANT HYPERTHERMIA: CASE REPORT \\ D.Damanskytè, K.Česevičiūtè, I.Razlevičè, L.Kalibatienė, T. Bukauskas, A.Macas}

Key words: malignant hyperthermia, complications of anesthesia, hypermetabolic syndrome.

Summary

Malignant hyperthermia ( $\mathrm{MH})$ is an inherited disorder of the musculoskeletal system, characterized by the development of hypermetabolic syndrome triggered by volatile anesthetics and/or depolarizing neuromuscular blocking agents. We present a case of malignant hyperthermia that occurred to 3 years old male child with a family history of $\mathrm{MH}$. Whereas, $\mathrm{MH}$ is a potentially fatal metabolic disorder, patient survival depends on the early detection of this hypermetabolic crisis and the onset of urgent treatment. Several conditions may present as acute $\mathrm{MH}$ perioperatively. Therefore, we describe the clinical manifestation, identification and management of this life-threatening condition.

Correspondence to: andrius.macas@kmuk.lt

Gauta 2018-04-25 